\title{
Estimation of the degradability of dietary protein in the sheep rumen by in vivo and in vitro procedures
}

\author{
By R. C. SIDDONS, J. PARADINE, D. L. GALE AND R. T. EVANS \\ The Animal and Grassland Research Institute, Hurley, Maidenhead, Berkshire SL6 5LR
}

(Received 8 November 1984 - Accepted 16 May 1985)

1. Estimates of degradability of nitrogen in the sheep rumen for a basal hay diet and for soya-bean meal (SBM), groundnut meal (GNM) and fish meal (FM), when given together with the hay, were determined from measurements of (1) duodenal $\mathrm{N}$ flow, (2) ammonia kinetics and (3) rumen $\mathrm{N}$ disappearance from polyester bags and rumen outflow rate. The ability of various in vitro procedures to predict in vivo $\mathrm{N}$ degradability was also examined.

2. Four sheep were given a basal hay diet ( $800 \mathrm{~g}$ dry matter (DM) and $19 \mathrm{~g} \mathrm{~N} / \mathrm{d}$ ) either alone or supplemented with isonitrogenous amounts $(15 \mathrm{~g} \mathrm{~N} / \mathrm{d})$ of SBM, GNM or FM. Duodenal non-ammonia-N flow $(\mathrm{g} / \mathrm{d})$ was increased more by FM (8.0) than by GNM (5.9) and SBM (5.8), whilst microbial $\mathrm{N}$ flow $(\mathrm{g} / \mathrm{d})$ was increased more by SBM (3.9) than by GNM (2.3) and FM (1.6). N degradability values calculated from these results were $0.88,0.76$ and 0.57 for the SBM, GNM and FM respectively. The corresponding value for hay was calculated to be 0.76 .

3. The irreversible loss of ammonia in the forestomachs ( $\mathrm{g} \mathrm{N} / \mathrm{d}$ ) was increased more by SBM (11.9) than by GNM (7.2) and FM (5.8), whilst ammonia outflow from the rumen ( $\mathrm{g} \mathrm{N} / \mathrm{d})$ was increased to a similar extent by all supplements $(1 \cdot 1,0.9$ and 0.8 respectively), as was the amount of microbial $\mathrm{N}(\mathrm{g} / \mathrm{d})$ synthesized from sources other than rumen ammonia $(1.8,2.0$ and 1.9 respectively). $\mathrm{N}$ degradability values calculated from these results were $0.84,0.54$ and 0.45 for the SBM, GNM and FM respectively.

4. The fractional rate of $\mathrm{N}$ disappearance $(/ \mathrm{h})$ when the feedstuffs were incubated in polyester bags in the rumen of sheep receiving the basal hay diet $(800 \mathrm{~g} \mathrm{DM} / \mathrm{d})$ was the highest for SBM $(0.145)$ and lowest for FM (0.037), with the hay $(0.082)$ and GNM $(0.071)$ intermediate, whilst the fractional outflow rates from the rumen $(/ \mathrm{h})$ of the three supplements were similar $(0.034,0.038$ and 0.030 for SBM, GNM and FM respectively). N degradability values calculated from these results were $0.82,0.67$ and 0.60 for the SBM, GNM and FM respectively; the value for the hay was 0.73 .

5. Of a number of in vitro procedures tested, only $\mathrm{N}$ solubility in sodium hydroxide and ammonia or total non-protein-N (NPN) production during incubation with rumen fluid in the absence of hydrazine sulphate ranked the supplements, although not the hay, in the same order as the in vivo degradability procedures. In terms of absolute values, $\mathrm{N}$ solubility in $\mathrm{NaOH}$, at room temperature, gave estimates similar to those derived from the duodenal flow measurements; estimates derived from ammonia and total NPN production were lower.

When formulating ruminant rations it is necessary to ensure an adequate supply of rumen-degradable nitrogen to meet microbial requirements, in order to optimize rumen fermentation, and also to ensure an adequate supply of dietary protein which will pass undegraded through the rumen to make up any deficit which may exist between the intestinal supply of rumen-synthesized microbial protein and tissue requirement for intestinally absorbed amino acids (Agricultural Research Council, 1980). Consequently, the total crude protein $(\mathrm{N} \times 6 \cdot 25)$ requirement in the diet is very sensitive to relatively small changes in its degradability (Ørskov, 1977), and ration formulation is dependent on reliable estimates of the extent to which the $\mathbf{N}$ fraction of feedstuffs is degraded in the rumen.

Protein degradability values presently ascribed to different feedstuffs have been determined either from measurements of digesta flow made in cannulated animals (MacRae, 1975) or from measurement of $\mathrm{N}$ degradation during incubation of feeds in polyester bags suspended in the rumen (Mehrez \& Orskov, 1977). Direct measurement of the amount of feed protein flowing at the abomasum or duodenum is limited to a few proteins having specific properties which allow their identification in digesta, e.g. casein and zein. For most feedstuffs this is not possible, and the quantity of feed protein reaching the abomasum or duodenum can only be obtained as a difference measurement, after making certain assumptions about the 
contribution of endogenous protein. On the other hand, determination of $\mathrm{N}$ degradability by the polyester bag procedure is dependent on the simultaneous measurement of rumen outflow rate (Ørskov \& McDonald, 1979) and, in most cases, the latter has not been measured but either it has been assumed or, alternatively, $\mathrm{N}$ loss at a specific incubation time (Mathers et al. 1977) or N loss relative to dry matter (DM) loss (Ørskov \& Mehrez, 1977) has been taken as the index of degradability. Despite the limitations of the two procedures, it would appear that they rank feedstuffs in a similar order, although the degree of agreement in terms of absolute degradability values is not known.

Neither of the previously mentioned procedures is suitable for the routine screening of feedstuffs, and alternative in vitro procedures such as $\mathrm{N}$ solubility or susceptibility to degradation by rumen microbes or proteolytic enzymes have been proposed (see Waldo, 1978; Osbourn \& Siddons, 1980). Again, the predictive ability of these in vitro procedures has been assessed only in terms of a generalized ranking of feedstuffs rather than by direct comparison with in vivo derived estimates. Therefore the present study was undertaken to compare the different procedures when used to estimate $\mathbf{N}$ degradability in the rumen of sheep given a basal diet of hay alone or with supplements of soya-bean meal (SBM), groundnut meal (GNM) or fish meal (FM).

\section{EXPERIMENTAL}

\section{Animals}

Four adult Suffolk $\times$ halfbred wethers weighing approximately $65 \mathrm{~kg}$ and each fitted with a rumen cannula and re-entrant cannulas in the proximal duodenum and distal ileum were used. They were housed individually in metabolism cages and given free access to a salt lick and drinking water.

\section{Measurements of duodenal flow and ammonia kinetics}

The basal ration consisted of $800 \mathrm{~g}$ chopped perennial ryegrass (Lolium perenne cv. Melle) hay $\mathrm{DM} / \mathrm{d}$, which was given either alone (diet $\mathrm{H}$ ) or together with isonitrogenous amounts $(15 \mathrm{~g} \mathrm{~N} / \mathrm{d})$ of either extracted SBM $(190 \mathrm{~g} \mathrm{DM} / \mathrm{d}$, diet HSBM), expeller GNM (176 $\mathrm{g} \mathrm{DM} / \mathrm{d}$, diet HGNM) or white FM (130 g DM/d, diet HFM). The GNM was received in a pelleted form but was crushed before feeding so that all supplements were given in a granular form. The daily allocation of each diet was given in 24 equal hourly portions using automatic feeders.

The diets were given to the sheep in an experiment of $4 \times 4$ Latin square design, and each period of the Latin square lasted 3 weeks. CrEDTA was continuously infused $(240 \mathrm{mg} \mathrm{Cr} / \mathrm{d}$ ) into the rumen during the last $10 \mathrm{~d}$ and $\left({ }^{15} \mathrm{NH}_{4}\right)_{2} \mathrm{SO}_{4}\left(960\right.$ atoms ${ }^{15} \mathrm{~N} / 1000$ atoms $\mathrm{N}$, $40 \mathrm{mg}{ }^{15} \mathrm{~N} / \mathrm{d}$ ) during the last $3 \mathrm{~d}$. All measurements were made during the last $9 \mathrm{~d}$ of each period. Individual rumen fluid samples were taken on $5 \mathrm{~d}$ for measurement of $\mathrm{pH}$, volatile fatty acids (VFA), ammonia, $\mathrm{Cr}$ and proteolytic activity (Siddons \& Paradine, 1981). A unit of proteolytic activity is equivalent to the production of $1 \mathrm{mg}$ non-protein-N (NPN) from casein during a $3 \mathrm{~h}$ incubation. Rumen fluid samples were also taken during the last $2 \mathrm{~d}$ of the ${ }^{15} \mathrm{~N}$ infusion for measurement of $\mathrm{N}$ enrichment of rumen ammonia. The disappearance of DM and $\mathrm{N}$ when samples of the four feedstuffs were incubated simultaneously in polyester bags in the rumen for $6 \mathrm{~h}$ was measured on $2 \mathrm{~d}$. On the last $2 \mathrm{~d}$ of the ${ }^{15} \mathrm{~N}$ infusion, representative samples of the total digesta flow were taken using automated sampling machines: part of the digesta was used to prepare a microbial sample by differential centrifugation (Siddons et al. 1982) and the remainder was freeze-dried. 


\section{Polyester bag study}

All four sheep were given continuously the basal hay diet ( $800 \mathrm{~g} \mathrm{DM} / \mathrm{d})$. The same hay was used in the bags but had been ground through a $3 \mathrm{~mm}$ sieve and then sieved through a $100 \mu \mathrm{m}$ sieve to remove fines. The SBM, GNM and FM were used as fed but with fines removed. Four polyester bags $(190 \mathrm{~mm} \times 100 \mathrm{~mm}, 43 \mu \mathrm{m}$ pore size $)$ containing a sample ( $5 \mathrm{~g} \mathrm{DM}$ ) of each of the feedstuffs were soaked in warm water before being placed in the rumen of each sheep. They were removed after a specified time $(3,6,9,12,18,24$ and $48 \mathrm{~h})$, washed with gentle squeezing in cold running water for $20 \mathrm{~min}$, and dried at $100^{\circ}$ for $24 \mathrm{~h}$ and the $\mathrm{N}$ content measured. Loss at each incubation time was determined on two separate days.

After completion of the polyester bag measurements, the rumen outflow rate of the supplements was determined: Cr mordants of the supplements, prepared by the procedure of Uden et al. (1980), were administered into the rumen of each sheep in the form of a slurry ( $40 \mathrm{~g} \mathrm{DM}$ containing approximately $2 \mathrm{~g} \mathrm{Cr}$ ). Six samples of whole rumen contents were taken daily over $2 \mathrm{~d}$ and total faeces excreted collected at approximately $6 \mathrm{~h}$ intervals over a period of $6 \mathrm{~d}$.

\section{In vitro studies}

In all procedures the hay and supplements used had been ground through a $0.8 \mathrm{~mm}$ sieve.

$N$ solubility. The solvents used were distilled water, McDougall's (1948) buffer, $0 \cdot 1 \mathrm{M}$ phosphate buffer ( $\mathrm{pH} 7.0$ ), $0.5 \mathrm{M}$-sodium chloride and $0.2 \mathrm{M}$-sodium hydroxide. A quantity of feedstuff equivalent to $20 \mathrm{mg} \mathrm{N}$ was incubated with $20 \mathrm{ml}$ solvent at $39^{\circ}$ for $1 \mathrm{~h}$ with regular mixing. The mixture was then centrifuged and the $\mathrm{N}$ content of the supernatant fraction measured. Soluble NPN was determined as the soluble $\mathrm{N}$ not precipitated by cold trichloroacetic acid (TCA) added to a final concentration of $50 \mathrm{~g} / 1$.

Digestion by proteolytic enzymes. The enzymes used were pepsin (1:10000, Zimmerman Hobbs Ltd) in $0 \cdot 1$ m-hydrochloric acid, pancreatin (BDH Chemicals Ltd, Poole, Dorset) and protease (Type XIV, 5.8 units/mg; Sigma Chemical Co., Poole, Dorset). The latter two enzymes were prepared in $0 \cdot 1 \mathrm{M}$-phosphate buffer, $\mathrm{pH} 7 \cdot 0$ with sodium azide $(0 \cdot 1 \mathrm{~g} / 1)$ added as a bacteriocide. Although enzyme:feedstuff $\mathrm{N}$ was varied, the standard procedure was as follows: a quantity of feedstuff containing $25 \mathrm{mg} \mathrm{N}$ was incubated with $10 \mathrm{ml}$ acid or buffer at $39^{\circ}$ for $10 \mathrm{~min}$ and then $40 \mathrm{ml}$ enzyme solution (pre-warmed to $39^{\circ}$ ) added. The mixture was incubated at $39^{\circ}$ and $5 \mathrm{ml}$ samples removed at specific times using a wide-bore pipette, into $1 \mathrm{ml} \mathrm{TCA}(300 \mathrm{~g} / 1)$. After cooling in iced water for $2 \mathrm{~h}$, the mixture was centrifuged and the $\mathrm{N}$ content of the supernatant fraction, i.e. soluble NPN, measured. Corrections were made for the soluble NPN production in blank incubations containing no substrate.

Digestion by rumen microbes. A quantity of feedstuff containing $20 \mathrm{mg} \mathrm{N}$ was incubated for $15 \mathrm{~min}$ at $39^{\circ}$ with $20 \mathrm{ml}$ buffer (McDougall, 1948) in tubes fitted with a bunsen valve. Strained rumen fluid $(20 \mathrm{ml})$ obtained from a sheep receiving the basal hay diet was then added and the tubes gassed with carbon dioxide and incubated at $39^{\circ}$. In some experiments $0.002 \mathrm{M}$-hydrazine sulphate was also included in the incubation mixture to inhibit amino acid deamination and ammonia uptake by the microbes. At specified times during the incubation, a sample $(5 \mathrm{ml})$ of the mixture was removed using a wide-bore pipette and mixed with $1 \mathrm{ml}$ TCA $(300 \mathrm{~g} / \mathrm{l})$. After cooling in iced water for $2 \mathrm{~h}$ and centrifuging, the total $\mathrm{N}$, i.e. soluble total NPN, and ammonia content of the supernatant fraction were measured. Corrections were made for soluble NPN and ammonia production in blank incubations containing no substrate. 


\section{Analytical methods}

Total $\mathrm{N}$ was determined by Kjeldahl digestion followed by an automated colorimetric procedure for measuring ammonia (Gehrke et al. 1968). VFA were determined by gas-solid chromatography on chromosorb 101, cellulose by the method of Van Soest \& Wine (1967), $\mathrm{Cr}$ by atomic absorption spectrometry and ${ }^{15} \mathrm{~N}$ by mass spectrometry, using lithium hypobromite to convert ammonium sulphate to $\mathrm{N}_{2}$ gas. The ammonia in rumen fluid and duodenal digesta was isolated by steam distillation. The NAN and the total N of duodenal digesta and the total $\mathrm{N}$ of the microbial fraction were converted to ammonium sulphate by Kjeldahl digestion and the ammonia then isolated by steam distillation. The diaminopimelic acid (DAPA) content of duodenal digesta and microbes was determined by automated ion-exchange chromatography.

\section{Calculations}

Duodenal flow study. Fluid outflow from the rumen was calculated by dividing the amount of $\mathrm{Cr}$ infused by the plateau concentration of $\mathrm{Cr}$ in rumen fluid. Nutrient flow at the duodenum was determined as the product of the ratio, nutrient: $\mathrm{Cr}$ in digesta, and the amount of $\mathrm{Cr}$ infused, and the proportion of microbial $\mathrm{N}$ in the duodenal NAN from the ${ }^{15} \mathrm{~N}$ enrichment ratio, duodenal NAN:microbial $\mathrm{N}$. The amount of supplement $\mathrm{N}$ passing undegraded through the forestomachs was calculated as the increase in non-microbial NAN flow at the duodenum when the supplements were given, whilst the amount of hay $\mathrm{N}$ passing undegraded through the forestomachs was calculated as the non-microbial NAN flow on the basal diet less $1.5 \mathrm{~g} / \mathrm{d}$ of endogenous NAN (Harrop, 1974).

Ammonia kinetics study. The irreversible loss rate (ILR) of ammonia and the proportion of the $\mathrm{N}$ in secondary pools which was derived from the rumen ammonia pool were estimated from plateau ${ }^{15} \mathrm{~N}$ enrichments and the ${ }^{15} \mathrm{~N}$ infusion rate as described by Nolan \& Leng (1974). The enrichment of ammonia- $\mathrm{N}$ in rumen fluid samples taken between 24 and $72 \mathrm{~h}$ after the start of the ${ }^{15} \mathrm{~N}$ infusion showed no consistent tendency to increase with time, and a mean value was taken as representing plateau enrichment. However, the enrichment of the various $N$ fractions in duodenal digesta collected between 24 and $48 \mathrm{~h}$ after the start of the infusion was consistently lower than the enrichment in the corresponding fractions in digesta collected between 48 and $72 \mathrm{~h}$. Therefore, the latter were assumed to represent plateau enrichment. The amount of supplement $\mathrm{N}$ degraded in the forestomachs was calculated as the increase, when the supplements were given, in the sum of ammonia-N ILR in the rumen and in the omasum, plus the increase in the duodenal flow of microbial $\mathrm{N}$ which was not derived from the rumen ammonia pool minus ammonia- $\mathrm{N}$ flowing out of the rumen in fluid.

Polyester bag study. Results for all four sheep for $\mathrm{N}$ disappearance $(y)$ with time $(t)$ during incubation of feedstuffs in polyester bags in the rumen were combined and fitted using an iterative procedure to the equation

$$
y=a+b\left(1-\mathrm{e}^{-k t}\right) .
$$

When all data points were used the predicted potential $\mathrm{N}$ degradability $(a+b)$ was very similar to the measured $\mathrm{N}$ loss at $48 \mathrm{~h}$ for the hay, SBM and GNM but for the FM it exceeded $100 \%$, i.e. $130 \%$. Therefore, for all feedstuffs the curve was fitted with the asymptote, i.e. the predicted potential degradability, fixed as the measured $48 \mathrm{~h} \mathrm{~N}$ loss. The fractional outflow rate $\left(k_{f}\right)$ of the supplements from the rumen was determined as the exponential decline in the $\mathrm{Cr}$ concentration of faecal samples taken between 72 and $120 \mathrm{~h}$ after an intraruminal dose of the $\mathrm{Cr}$-mordanted supplements (Grovum \& Williams, 
Table 1. Rumen measurements in sheep given a basal hay diet, either unsupplemented $(H)$ or supplemented with soya-bean meal (SBM), groundnut meal (GNM) or fish meal (FM)

(Mean values for four sheep)

\begin{tabular}{lccccc}
\hline \multicolumn{1}{c}{ Diet... } & H & HSBM & HGNM & HFM & SEM \\
\hline pH & 6.6 & 6.5 & 6.5 & 6.5 & 0.04 \\
Fluid outflow (1/d) & $8 \cdot 5$ & $9 \cdot 1$ & $8 \cdot 2$ & $8 \cdot 0$ & 0.35 \\
Total VFA (mM) & 78.8 & 89.8 & 90.6 & 79.0 & 4.91 \\
VFA molar proportions & & & & & \\
$\quad$ Acetate & $0.78^{\mathrm{a}}$ & $0.76^{\mathrm{bc}}$ & $0.75^{\mathrm{c}}$ & $0.77^{\mathrm{ab}}$ & 0.003 \\
$\quad$ Propionate & 0.16 & 0.17 & 0.18 & 0.17 & 0.004 \\
$\quad$ Butyrate & 0.06 & 0.07 & 0.07 & 0.06 & 0.003 \\
Ammonia nitrogen (mg/l) & $157^{\mathrm{b}}$ & $271^{\mathrm{a}}$ & $271^{\mathrm{a}}$ & $269^{\mathrm{a}}$ & 9.4 \\
Proteolytic activity (units/ml) & 1.49 & 1.78 & 1.62 & 1.46 & 0.086 \\
\hline \hline
\end{tabular}

VFA, volatile fatty acids.

$\mathbf{a}, \mathbf{b}, \mathbf{c}$ Means with different superscript letters differed significantly $(P<0.05)$.

1973). The proportion of the supplement $\mathbf{N}$ degraded in the rumen $(p)$ was estimated from the polyester bag and rumen outflow rates as

$$
p=a+\frac{b k}{k+k_{f}}
$$

(Ørskov \& McDonald, 1979). Since the outflow rate of the hay was not determined an assumed value $(0 \cdot 03 / \mathrm{h})$ was used.

\section{Statistical analysis}

Analysis of variance was used to identify significant effects, and treatment means were compared using Newman-Keuls' test (Miller, 1966).

\section{RESULTS}

In vivo studies

Rumen measurements. Supplementation of the basal diet with either SBM, GNM or FM had no effect $(P>0.05)$ on the $\mathrm{pH}$ and quantity of fluid flowing from the rumen (Table 1). Total VFA concentration in the rumen tended to be increased by SBM and GNM, but the effect was not significant $(P>0.05)$ and there was also little if any effect on the molar proportions of the individual VFA. The most marked effect of the supplements was on the rumen ammonia concentration, which was increased $(P<0.05)$ to a similar extent by all supplements. The effect of the supplements on the degradative activity of the rumen microbial population was assessed in terms of the proteolytic activity of rumen fluid and the degradation of DM and $\mathrm{N}$ when the hay and the supplements were incubated for $6 \mathrm{~h}$ in polyester bags in the rumen (Table 2). Neither indicated any change $(P>0.05)$ in the degradative activity in the rumen due to the supplements.

Digestion in the forestomachs. The digestion of $\mathrm{OM}$, cellulose and $\mathrm{N}$ between mouth and duodenum is shown in Table 3. Both the intake and duodenal flow $(P<0 \cdot 05)$ of OM were higher when the supplemented diets were given, but the apparent digestibility of OM did not differ significantly $(P>0.05)$ from that when the basal hay diet was given. Similarly, the supplements had no effect $(P>0.05)$ on cellulose digestibility in the forestomachs. All 
Table 2. Dry matter $(D M)$ and nitrogen disappearance $(\%)$ when samples of hay, soya-bean meal (SBM), groundnut meal (GNM) and fish meal (FM) were incubated for $6 \mathrm{~h}$ in polyester bags in the rumen of sheep given a basal hay diet either unsupplemented $(H)$ or supplemented with SBM, GNM or FM

(Mean values for four sheep)

\begin{tabular}{ccccccc}
\hline \hline \multirow{2}{*}{$\begin{array}{c}\text { Sample } \\
\text { incubated }\end{array}$} & Constituent & \multicolumn{5}{c}{ Diet } \\
\cline { 3 - 6 } & H & HSBM & HGNM & HFM & SEM \\
\hline Hay & DM & 34 & 35 & 37 & 35 & $1 \cdot 0$ \\
& N & 57 & 55 & 58 & 55 & $1 \cdot 4$ \\
SBM & DM & 60 & 61 & 57 & 60 & $1 \cdot 8$ \\
& N & 60 & 62 & 58 & 61 & $2 \cdot 1$ \\
GNM & DM & 39 & 40 & 41 & 43 & $1 \cdot 6$ \\
& N & 37 & 38 & 40 & 39 & $1 \cdot 6$ \\
FM & DM & 35 & 34 & 36 & 35 & $0 \cdot 7$ \\
& N & 43 & 43 & 44 & 42 & 0.8 \\
\hline \hline
\end{tabular}

supplements increased total $\mathrm{N}$ intake by $15 \mathrm{~g} / \mathrm{d}$ and also increased $(P<0.05)$ the duodenal flows of total N, ammonia-N and NAN. The increases in total N and NAN flow were greater $(P<0.05)$ with FM than with SBM and GNM, whereas ammonia-N flow was increased to a similar $(P>0.05)$ extent by all supplements. Estimates of microbial $\mathrm{N}$ flow at the duodenum were obtained using both ${ }^{15} \mathrm{~N}$ and DAPA as markers, and both gave very similar mean estimates for a particular diet. The flow of microbial $\mathrm{N}$ was increased by all supplements and more by SBM than by GNM and FM, although only for the ${ }^{15} \mathrm{~N}$-based estimates were these differences significant $(P<0.05)$.

Ammonia kinetics in the forestomachs. Ammonia-N ILR in the rumen, absorption from the rumen and net incorporation into microbial $\mathrm{N}$ all tended to be higher when the supplemented diets were given, and the increases tended to be greater with SBM than with GNM and FM, although most of the differences were not significant $(P>0.05$, Table 4). Ammonia $\mathrm{N}$ outflow from the rumen was increased $(P<0.05)$ to a similar extent by all supplements, and with each diet the quantity of ammonia- $\mathrm{N}$ leaving the rumen was similar to that reaching the duodenum (Table 3 ). However, only approximately 0.6 of the duodenal ammonia- $\mathrm{N}$ originated from the rumen ammonia pool, indicating that ammonia was produced between the rumen and duodenum, most probably in the omasum, and that an equivalent quantity of ammonia was also absorbed from the omasum or the abomasum, or both. Ammonia-N ILR in the omasum tended to be higher when the supplemented diets were given, although much of the difference was due to ammonia entering by outflow from the rumen, whilst ammonia- $\mathrm{N}$ absorption from the omasum or abomasum was similar with all diets.

Polyester bag $N$ degradation and rumen outflow rate. Fractionation of the $\mathrm{N}$ of the feedstuffs into that which was potentially degradable in the rumen, the readily soluble fraction and the insoluble but degradable fraction, is shown in Table 5. Practically all the $\mathrm{N}$ in the SBM and GNM was potentially degradable, whereas a proportion of the FM (0.19) and hay $\mathrm{N}(0 \cdot 14)$ was resistant to degradation. The predicted soluble $\mathrm{N}$ content of the FM and hay was very similar to the measured soluble $\mathrm{N}$ content (i.e. $\mathrm{N}$ loss on washing), whereas for the SBM and GNM the predicted soluble $\mathrm{N}$ was much lower than the measured soluble N. However, for all feedstuffs the estimated lag time before digestion commenced, which was derived as the time on the fitted curve which equated with the $\mathbf{N}$ loss on washing, was short. The insoluble but degradable fraction constituted a greater proportion of the total 
Table 3. Organic matter $(O M)$, cellulose and nitrogen digestion in the forestomachs of sheep given a basal hay diet, either unsupplemented $(H)$ or supplemented with soya-bean meal $(S B M)$, groundnut meal (GNM) or fish meal (FM)

(Mean values for four sheep)

\begin{tabular}{lccccc}
\hline \multicolumn{1}{c}{ Diet... } & H & HSBM & HGNM & HFM & SEM \\
\hline OM & & & & & \\
Intake (g/d) & 737 & 915 & 905 & 841 & \\
Duodenal flow (g/d) & $357^{\mathrm{b}}$ & $417^{\mathrm{a}}$ & $.429^{\mathrm{a}}$ & $430^{\mathrm{a}}$ & $8 \cdot 6$ \\
$\quad$ Apparent digestibility & $0 \cdot 51^{\mathrm{ab}}$ & $0 \cdot 54^{\mathrm{a}}$ & $0 \cdot 53^{\mathrm{ab}}$ & $0 \cdot 49^{\mathrm{b}}$ & $0 \cdot 01$ \\
Cellulose & & & & & \\
Intake (g/d) & 245 & 266 & 262 & 246 & \\
Duodenal flow (g/d) & 62 & 65 & 68 & 61 & $2 \cdot 3$ \\
Digestibility & $0 \cdot 75$ & $0 \cdot 76$ & $0 \cdot 74$ & $0 \cdot 75$ & $0 \cdot 01$ \\
Nitrogen & & & & & \\
Total N intake (g/d) & $19 \cdot 0$ & $33 \cdot 9$ & $34 \cdot 0$ & $33 \cdot 9$ & \\
Duodenal flow (g/d) & $18 \cdot 4^{\mathrm{c}}$ & $25 \cdot 3^{\mathrm{b}}$ & $25 \cdot 2^{\mathrm{b}}$ & $27 \cdot 4^{\mathrm{a}}$ & $0 \cdot 24$ \\
$\quad$ Total N & $1 \cdot 3^{\mathrm{b}}$ & $2 \cdot 4^{\mathrm{a}}$ & $2 \cdot 2^{\mathrm{a}}$ & $2 \cdot 4^{\mathrm{a}}$ & $0 \cdot 06$ \\
$\quad$ Ammonia N & $17 \cdot 1^{\mathrm{c}}$ & $22 \cdot 9^{\mathrm{b}}$ & $23 \cdot 0^{\mathrm{b}}$ & $25 \cdot 1^{\mathrm{a}}$ & $0 \cdot 27$ \\
$\quad$ Non-ammonia N & $11 \cdot 1^{\mathrm{c}}$ & $15 \cdot 0^{\mathrm{a}}$ & $13 \cdot 4^{\mathrm{b}}$ & $12 \cdot 7^{\mathrm{b}}$ & $0 \cdot 34$ \\
$\quad$ Microbial N*: 15N & $11 \cdot 7^{\mathrm{b}}$ & $14 \cdot 9$ & $12 \cdot 1$ & $12 \cdot 3$ & $0 \cdot 77$ \\
DAPA & $29 \cdot 2$ & $30 \cdot 1$ & $28 \cdot 1$ & $30 \cdot 8$ & $1 \cdot 18$ \\
Efficiency of microbial N & & & & & \\
synthesis (g/kg OMADR) & & & & & \\
\hline \hline
\end{tabular}

OMADR, OM apparently digested in the rumen.

a, b, c Means with different superscript letters differed significantly $(P<0.05)$.

* Estimates based on either ${ }^{15} \mathrm{~N}$ or diaminopimelic acid as the microbial marker.

N of the SBM and GNM than of the hay and FM, whilst the degradation rate constant of this fraction was highest for SBM and lowest for FM.

Determination of the fractional outflow rates of the supplements from the rumen, from the decrease with time in the $\mathrm{Cr}$ concentration of rumen digesta following an intraruminal dose of the $\mathrm{Cr}$-mordanted supplements was unsuccessful, presumably due to unrepresentative sampling of the rumen contents. Computer fitting of a two-pool exponential model (Grovum \& Williams, 1973) to the change with time in the faecal $\mathrm{Cr}$ concentration also proved not to be possible. Therefore, the fractional outflow rates of the supplements were determined from the post-peak exponential decline in faecal $\mathrm{Cr}$ concentration and are presented in Table 5. The values obtained were similar for all supplements and slightly lower than that determined for CrEDTA $(0.043 / \mathrm{h})$ using the same technique, whilst the outflow rate of CrEDTA determined by rumen fluid sampling was $0 \cdot 055 / \mathrm{h}$.

$N$ degradability. Estimates of degradability of feedstuff $\mathrm{N}$ derived from duodenal flow, ammonia kinetics and polyester bag measurements are presented in Table 6. Incorporation of the lag time (McDonald, 1981) had little (less than 1 percentage unit) or no effect on the polyester bag-derived estimates. All three procedures ranked the feedstuffs in a similar order, with SBM the most degradable, FM the least degradable and the hay and GNM intermediate. In terms of absolute values the agreement between the duodenal flow and polyester bag procedures was reasonably good for the SBM, FM and hay, but less good for the GNM. The polyester bag estimate for SBM was slightly lower than the duodenal flow estimate, whereas the estimate for FM was slightly higher, such that the range in the degradability values was greater with the duodenal flow procedure $(0 \cdot 88-0.57)$ than with 
Table 4. Ammonia kinetics ( $g$ nitrogen $/ d$ ) in the forestomachs of sheep receiving a basal hay diet either unsupplemented $(H)$ or supplemented with soya-bean meal $(S B M)$, groundnut meal $(G N M)$ or fish meal $(F M)$

(Mean values for four sheep)

\begin{tabular}{|c|c|c|c|c|c|}
\hline Diet... & $\mathrm{H}$ & HSBM & HGNM & HFM & SEM \\
\hline \multicolumn{6}{|l|}{ Rumen ammonia } \\
\hline Irreversible loss & $15 \cdot 1^{\mathrm{b}}$ & $25 \cdot 8^{\mathrm{a}}$ & $20 \cdot 6^{\mathrm{ab}}$ & $19 \cdot 4^{\mathrm{ab}}$ & $1 \cdot 80$ \\
\hline Outflow in fluid & $1 \cdot 4^{b}$ & $2 \cdot 5^{\mathfrak{a}}$ & $2 \cdot 3^{\mathrm{a}}$ & $2 \cdot 2^{\mathrm{a}}$ & 0.15 \\
\hline Incorporation into microbes & $5 \cdot 9$ & $8 \cdot 0$ & $6 \cdot 2$ & $5 \cdot 6$ & 0.46 \\
\hline Absorption & $7 \cdot 8$ & $15 \cdot 2$ & $12 \cdot 1$ & $11 \cdot 5$ & $1 \cdot 51$ \\
\hline \multicolumn{6}{|l|}{ Omasal-abomasal ammonia } \\
\hline Irreversible loss & $2 \cdot 4$ & $3 \cdot 6$ & $4 \cdot 1$ & $3 \cdot 9$ & $0 \cdot 36$ \\
\hline Absorption & $1 \cdot 0$ & 0.9 & 1.6 & $1 \cdot 3$ & $0 \cdot 39$ \\
\hline $\begin{array}{l}\text { Proportion of microbial } \mathrm{N} \\
\text { derived from rumen ammonia }\end{array}$ & 0.52 & 0.55 & 0.47 & 0.44 & $0 \cdot 040$ \\
\hline $\begin{array}{l}\text { Proportion of duodenal ammonia } \\
\text { derived from rumen ammonia }\end{array}$ & 0.60 & 0.68 & 0.57 & $0 \cdot 58$ & 0.050 \\
\hline
\end{tabular}

a,b Means with different superscript letters differed significantly $(P<0 \cdot 05)$.

Table 5. Polyester-bag nitrogen degradability $(\%$ total $N)$ and rumen outflow rates of the hay, soya-bean meal (SBM), groundnut meal (GNM) and fish meal (FM)

\begin{tabular}{lcccc}
\hline & Hay & SBM & GNM & FM \\
\hline Soluble N & & & & \\
$\quad$ Measured & 41 & 25 & 20 & 33 \\
$\quad$ Predicted* & 36 & 3 & 7 & 32 \\
Potentially degradable N* & 86 & 100 & 98 & 81 \\
Insoluble degradable N* & 50 & 97 & 91 & 49 \\
Degradation rate-constant (/h) & 0.082 & 0.145 & 0.071 & 0.037 \\
Lag time (h) & 1.3 & 1.8 & 2.2 & 0.5 \\
Rumen outflow rate-constant $(/ \mathrm{h})$ & ND & 0.034 & 0.038 & 0.030 \\
\hline \hline
\end{tabular}

ND, not determined.

* Degradation curves were described by equations of the form $y=a+b\left(1-\mathrm{e}^{-k t}\right)$ (see $\mathrm{p}$. 548), where predicted soluble $\mathrm{N}(a)$, potentially degradable $\mathrm{N}(a+b)$, insoluble degradable $\mathrm{N}(b)$ and degradation rate-constant $(k)$ values were derived from the fitted curves.

the polyester bag procedure $(0 \cdot 82-0 \cdot 60)$. The ammonia kinetics procedure gave similar estimates for SBM as the other two procedures but lower estimates for GNM and FM.

In vitro studies

Solubility. The solubility of feedstuff $\mathrm{N}$ in McDougall's (1948) buffer, phosphate buffer, $\mathrm{NaCl}$, distilled water or $\mathrm{NaOH}$ is shown in Table 7. Apart from $\mathrm{NaOH}$ the differences between the solvents were very small: all ranked the feedstuffs in the same order, with the hay having the highest proportion of soluble $\mathrm{N}$ and the GNM the lowest; most of the soluble $\mathrm{N}$ in the hay and FM was in the form of NPN, i.e. was soluble in TCA, whereas with the SBM and GNM a much higher proportion of the soluble $N$ was insoluble in TCA and therefore probably in the form of protein. $\mathrm{NaOH}$ solubilized considerably more of the total $\mathrm{N}$ than the other solvents and also ranked the supplements, but not the hay, in the same 
Table 6. Nitrogen degradability $(\%)$ estimates for hay, soya-bean meal (SBM), groundnut meal (GNM) and fish meal (FM) derived by three different methods

\begin{tabular}{lcccc}
\hline & Hay & SBM & GNM & FM \\
\hline Duodenal flow & 76 & 88 & 76 & 57 \\
Ammonia kinetics & ND & 84 & 54 & 45 \\
Polyester bag & 73 & 82 & 67 & 60 \\
\hline
\end{tabular}

ND, not determined.

Table 7. Nitrogen solubility $(\%)$ of hay, soya-bean meal (SBM), groundnut meal (GNM) and fish meal $(F M)$ in different solvents

(Soluble non-protein-N (\% total soluble $\mathrm{N}$ ) given in parentheses)

\begin{tabular}{lccrc}
\hline & Hay & SBM & GNM & FM \\
\hline McDougall's (1948) buffer & $37(85)$ & $25(16)$ & $15(41)$ & $23(83)$ \\
Phosphate buffer & $38(85)$ & $28(13)$ & $15(44)$ & $23(84)$ \\
Sodium chloride & $35(94)$ & $22(18)$ & $12(54)$ & $21(82)$ \\
Distilled water & $36(94)$ & $17(19)$ & $9(60)$ & $19(90)$ \\
Sodium hydroxide & & & & \\
$39^{\circ}$ & $56(58)$ & $95(13)$ & $80(15)$ & $74(34)$ \\
Room temperature & $49(64)$ & $86(10)$ & $73(12)$ & $54(42)$ \\
\hline \hline
\end{tabular}

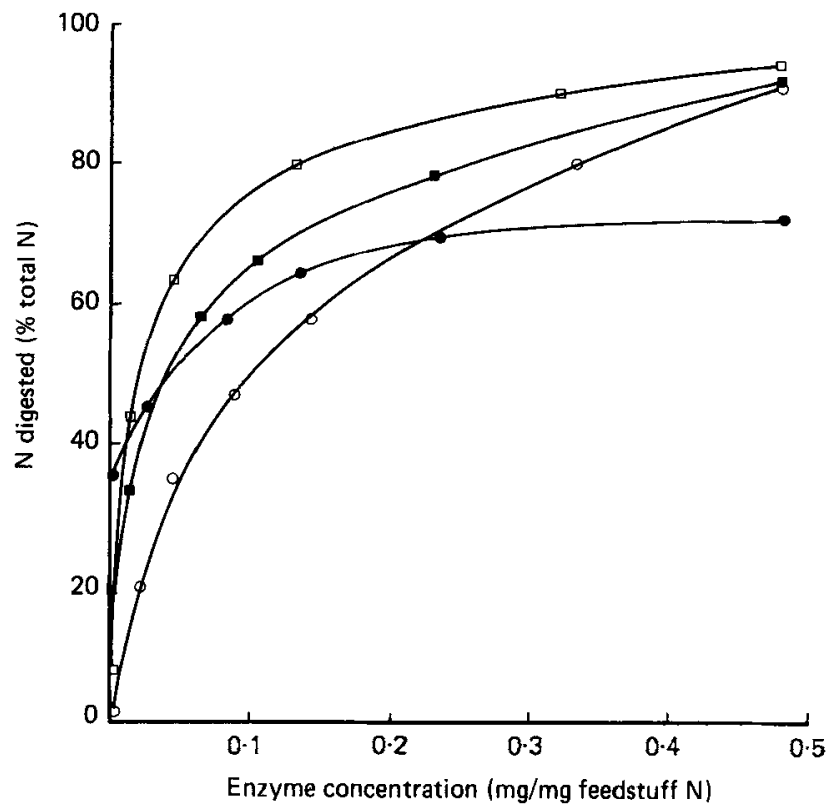

Fig. 1. Effect of enzyme: substrate value on the amount of feedstuff nitrogen digested during an $18 \mathrm{~h}$ incubation of hay $(\Theta)$, soya-bean meal $(O)$, groundnut meal $(\square)$ and fish meal $(\square)$ with protease at $39^{\circ}$. 

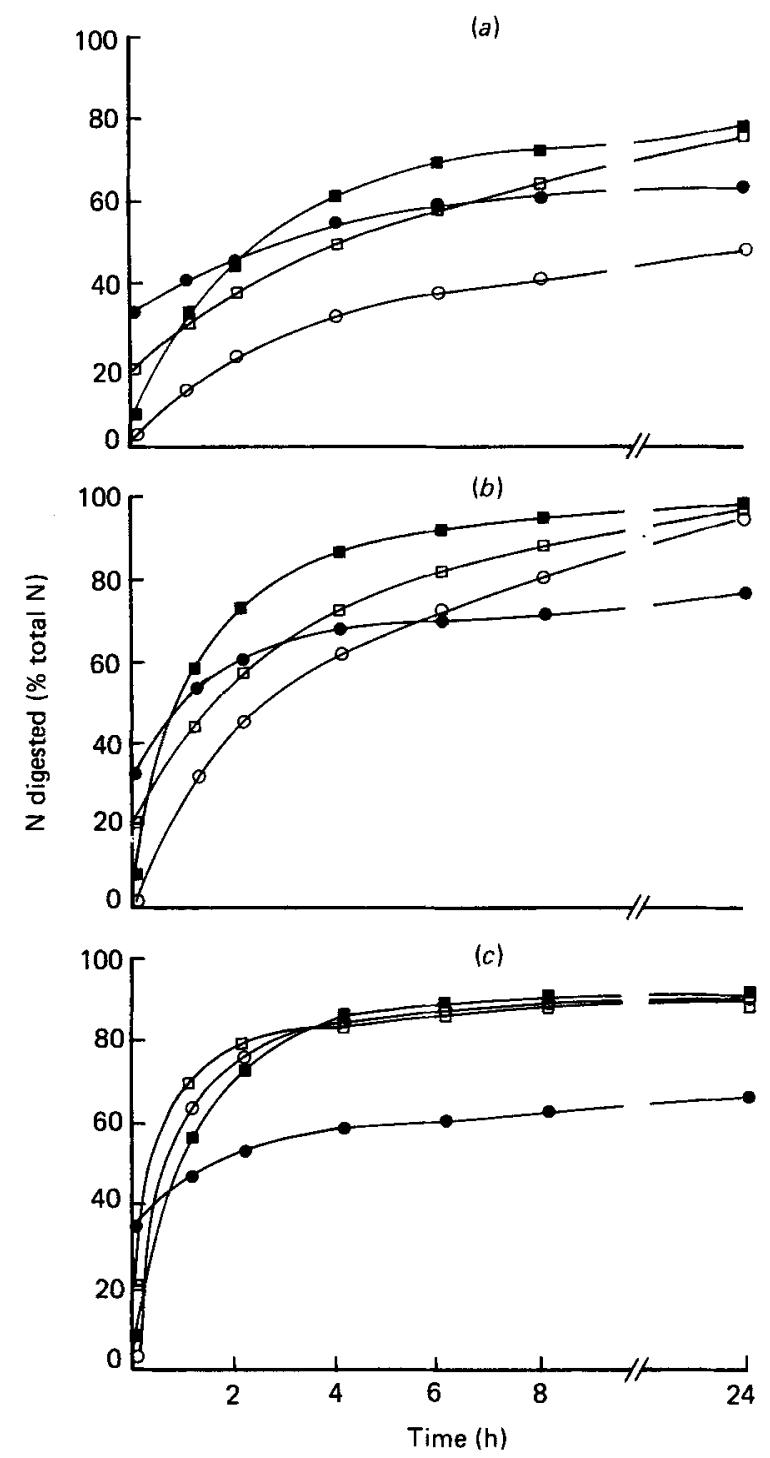

Fig. 2. The rate of feedstuff nitrogen digestion during incubation of hay $(\bullet)$, soya-bean meal $(O)$, groundnut meal ( $\boldsymbol{\square})$ and fish meal ( $\square$ ) with: (a) pancreatin, (b) protease, or (c) pepsin $(0.44 \mathrm{mg}$ enzyme $/ \mathrm{mg}$ substrate $\mathrm{N})$.

order as the in vivo degradability procedures. Furthermore, when the extraction was carried out at room temperature the proportion of the supplement $\mathrm{N}$ solubilized was very similar to the $\mathbf{N}$ degradability estimate derived from duodenal flow measurements. However, the proportion of the hay total $\mathrm{N}$ solubilized by $\mathrm{NaOH}$ was lower than the estimate of $\mathrm{N}$ degradability derived from duodenal flow measurement.

Digestion with proteolytic enzymes. The susceptibility of feedstuff $\mathrm{N}$ to digestion by proteolytic enzymes was examined using pepsin, pancreatin and protease. With all three enzymes and for all feedstuffs both the rate and extent of $\mathrm{N}$ digestion altered as the 

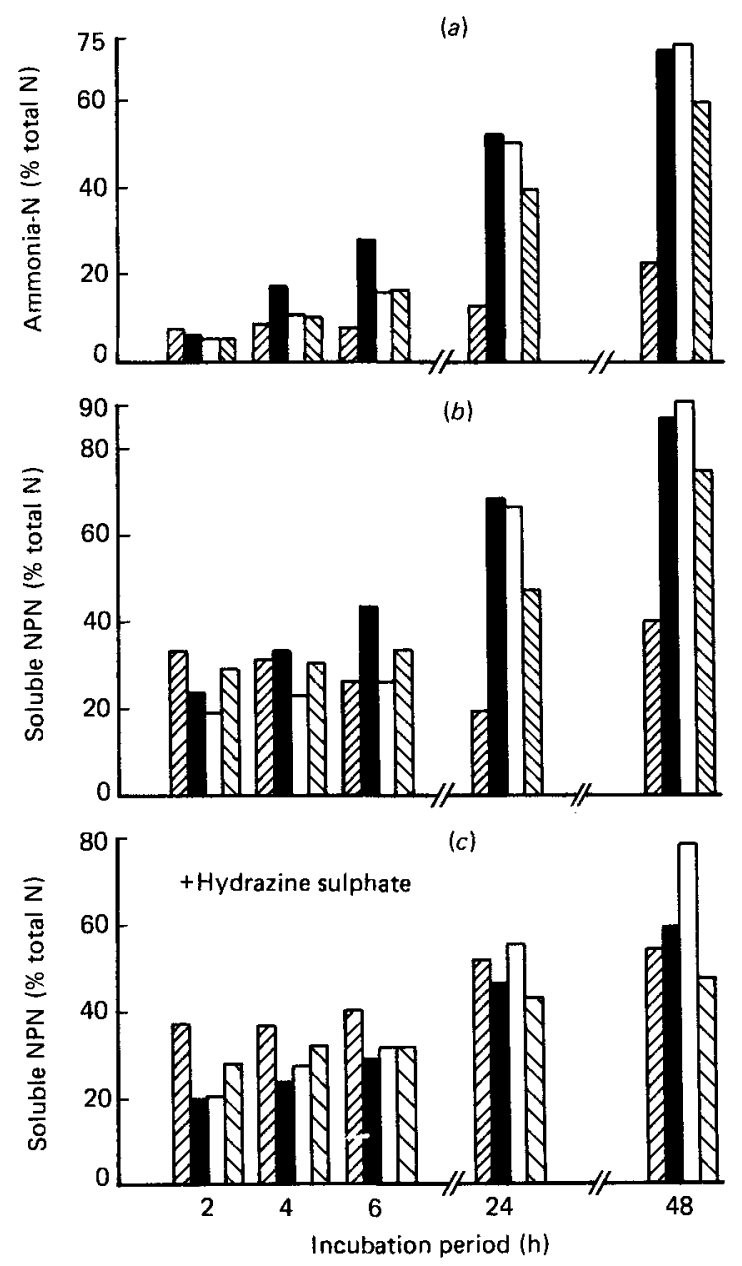

Fig. 3. Feedstuff nitrogen degraded during incubation of hay $(\boldsymbol{Z})$, soya-bean meal $(\boldsymbol{E})$, groundnut meal $(\square)$ and fish meal $(\nabla)$ with rumen fluid; $(a)$ ammonia-N production, $(b)$ and $(c)$ soluble total non-protein- $\mathrm{N}$ (NPN) production, expressed as \% feedstuff total $\mathrm{N}$.

enzyme: substrate value was altered. This is shown graphically in Fig. 1 in terms of the effect of the protease concentration on the extent of digestion. As the enzyme:substrate value increased so the proportion of the total $\mathrm{N}$ digested increased, but the rate of increase varied between feedstuffs such that at low enzyme:substrate values, SBM was digested to a lesser extent than the other feedstuffs, whereas at higher enzyme:substrate values the three supplements were digested to a similar extent and the hay to a lesser extent. The rate of feedstuff $\mathrm{N}$ digestion with time at a fixed enzyme: substrate value is shown in Fig. 2. All feedstuffs were less susceptible to digestion by pancreatin than by pepsin and protease. The proportion of the total $\mathrm{N}$ digested by pancreatin was at all incubation times lower for SBM than for the other three feedstuffs. Protease also digested less of the SBM-N at shorter incubation times, but as incubation time increased the proportion of the SBM-N digested approached that of the GNM and FM and was higher than that of the hay. The susceptibility of the supplements to digestion by pepsin was similar and greater than that 
of the hay. Thus it was not possible to identify conditions whereby digestion with any of the three enzymes ranked the feedstuffs in the same order as the in vivo $\mathrm{N}$ degradability procedures.

Degradation by rumen microbes. Feedstuff $\mathrm{N}$ degradation during anaerobic incubation with rumen fluid was assessed in terms of ammonia production and soluble total NPN production (Fig. 3). Apart from the $2 \mathrm{~h}$ incubation, ammonia production with the hay was always lower than with the supplements. With the supplements ammonia production increased with time, but whereas up to $6 \mathrm{~h}$ incubation it was very similar for GNM and FM and higher for SBM, after 24 and $48 \mathrm{~h}$ incubation it was very similar for GNM and SBM and lower for FM. The pattern of soluble total NPN production was generally similar to that of ammonia, although amounts were higher. Thus, it would appear that measurement of either ammonia or soluble total NPN production after an incubation time of between 6 and $24 \mathrm{~h}$ would rank the supplements, but not the hay, in the same order as the in vivo degradability procedures, but the absolute values would be lower. The inclusion of hydrazine sulphate in the incubation mixture increased soluble total NPN production with the hay, but with the supplements it either had no effect or reduced total NPN production. The reduction was more marked with SBM than with GNM, such that at no incubation time did soluble total NPN production in the presence of hydrazine sulphate rank the feedstuffs in the same order as the in vivo degradability procedures.

\section{DISCUSSION}

The amount of feed $\mathbf{N}$ degraded in the rumen is the sum of that which is converted to ammonia either directly or via microbial $\mathrm{N}$ recycling, and that which leaves the rumen in the form of microbial $\mathrm{N}$ after incorporation as amino acids, i.e. without previous conversion to ammonia. Since duodenal digesta contains ammonia and also endogenous $\mathrm{N}$, the determination of undegraded feed $\mathrm{N}$ as the difference between the total $\mathrm{N}$ and microbial $\mathrm{N}$ flow at the duodenum (Agricultural Research Council, 1980) will overestimate the true flow of feed $\mathbf{N}$ and underestimate degradability. On the other hand, duodenal flow estimates of degradability reflect the degradability in the forestomachs rather than that occurring specifically in the rumen, as is the case with the polyester bag procedure. The ammonia kinetic studies showed that ammonia was produced between rumen and duodenum, and this most probably occurred in the omasum (Engelhardt \& Hauffe, 1975). With SBM the amount was small, and represented $<1 \%$ of the total $\mathrm{N}$ degraded between mouth and duodenum, but with GNM and FM it represented a greater percentage. If this ammonia was produced by degradation of feed $\mathrm{N}$ rather than by degradation of endogenous or microbial $\mathrm{N}$, the estimates of $\mathrm{N}$ degradability in the rumen, based on the ammonia kinetics results, would be 0.49 and 0.41 for GNM and FM respectively, compared with forestomach $\mathrm{N}$ degradability estimates of 0.54 and 0.45 respectively.

\section{Duodenal-flow-derived degradability estimates}

Degradabilities derived from digesta flow measurements are obtained by difference, and therefore are subject to errors in the determination of both total $\mathbf{N}$ and microbial $\mathbf{N}$ flow and also in the allowance made for endogenous $\mathbf{N}$. Reasonably reliable measurement of digesta flow can be achieved using re-entrant cannulas and automated sampling equipment (MacRae, 1975), provided that the digesta flow marker is not absorbed to any significant extent. Studies (Faichney, 1975) have shown that CrEDTA is absorbed between rumen and duodenum, but the amount is very small (less than $2 \%$ of that infused), and if this was so in the present study it would have very little, if any, effect on the estimates of $N$ degradability. Values for microbial $\mathrm{N}$ flow determined using ${ }^{15} \mathrm{~N}$ or DAPA were very similar, whereas 
in a previous study (Siddons et al. 1982) the DAPA procedure gave consistently higher results. There were methodological differences between the two studies in that in the present study the microbial fraction was isolated from duodenal digesta rather than from rumen fluid, and the DAPA was estimated by automated rather than manual ion-exchange chromatography. In the previous study (Siddons et al. 1982) it was concluded that the ${ }^{15} \mathrm{~N}$ method was probably the most reliable method presently available for estimating microbial N.

Endogenous $\mathrm{N}$ fiow at the sheep duodenum is generally thought to be between 1 and $2 \mathrm{~g} / \mathrm{d}$ (Harrop, 1974) and a value of $1.5 \mathrm{~g} / \mathrm{d}$ was assumed in the present study in calculating the $\mathrm{N}$ degradability of the hay. Calculation of the amount of undegraded supplement $\mathrm{N}$ reaching the duodenum as the increase in the flow of non-microbial NAN when the supplements were given, obviates the need to make any absolute allowance for endogenous $\mathrm{N}$, but is dependent on the quantity of endogenous $\mathrm{N}$ reaching the duodenum and also the digestion of the basal hay diet being constant across all diets. Only indirect evidence is available to support a lack of effect of the supplements on the digestion of the hay. Thus, although the amount of OM apparently digested in the forestomachs was increased by the supplements, the apparent digestibility of $\mathrm{OM}$ and also cellulose digestibility were not altered; microbial $\mathrm{N}$ flow at the duodenum also increased, but the efficiency of microbial $\mathrm{N}$ synthesis was unaffected; the proportions of microbial $\mathrm{N}$ and duodenal ammonia $\mathrm{N}$ derived from the rumen ammonia pool were the same with all diets; and the degradative activity in the rumen, assessed as the proteolytic activity of rumen fluid or as feedstuff degradation during incubation in polyester bags in the rumen, was unchanged.

The $\mathrm{N}$ degradability values determined from the duodenal flow results were generally as expected, with the hay, SBM and GNM being degraded to a greater extent than the FM. It has been suggested that the presence of cellulose may explain the increased susceptibility of plant protein supplements compared with FM to microbial degradation (Ganev et al. 1979; Siddons \& Paradine, 1981, 1983). The lower degradability of the GNM compared with SBM may have been due to the effect of heat produced during the pelleting process it had undergone during preparation (see p. 546).

\section{Ammonia-kinetics-derived degradability estimates}

On the basis that ammonia is the major end-product of feed $\mathrm{N}$ degradation in the rumen, the finding that rumen ammonia concentration was increased to a similar extent by all supplements might be considered as indicating that the supplements were degraded to the same extent. However, the concentration of ammonia in the rumen is the net result of its rate of production by degradation of feed, microbial and endogenous $\mathrm{N}$, and its rate of loss by absorption and by outflow either as ammonia or after incorporation into microbial $\mathbf{N}$. Under steady-state conditions production will balance loss, and was found to be increased more by SBM than by GNM and FM. Ammonia was also produced in the omasum, as discussed earlier. Taking the increase in ammonia $\mathrm{N}$ production in the rumen and omasum together with the increase in microbial $\mathrm{N}$ synthesized from sources other than rumen ammonia, when the supplements were given, as a measure of supplement $\mathrm{N}$ degraded, yielded $\mathrm{N}$ degradability estimates which ranked the supplements in the same order as the duodenal-flow procedure, although the absolute values for GNM and FM were lower.

As with the duodenal-flow procedure, the ammonia-kinetics procedure is dependent on the metabolism of the basal hay diet being unaffected by the supplements and, in addition, since ILR is not a measure of total production, it is also dependent on ${ }^{15} \mathrm{~N}$ recycling to the rumen ammonia pool in the form of endogenous $\mathrm{N}$ being proportional to the rumen ammonia- $\mathrm{N}$ enrichment. It is not possible to say whether this was so, although estimates 
of total endogenous $\mathrm{N}$ entry to the forestomachs can be obtained on the basis that under steady-state conditions $\mathrm{N}$ inputs to the forestomachs (dietary and endogenous) must equal $\mathrm{N}$ losses (outflow to duodenum and absorption). Total endogenous $\mathbf{N}$ entry to the forestomachs was $8 \cdot 2,7.5,4.9$ and $6.3 \mathrm{~g} / \mathrm{d}$ when diets H, HSBM, HGNM and HFM, respectively, were given. The amount by which the endogenous $\mathrm{N}$ entry was lower with the supplemented diets than with the basal hay diet represents the amount by which the supplement $\mathrm{N}$ degraded in the forestomachs calculated from the ammonia-kinetic results was lower than that calculated from the duodenal-flow results. This should not be construed as suggesting that the duodenal-flow procedure gives true degradabilities, but is simply a consequence of using the same conceptual framework in deriving the same answer by two different routes.

\section{Polyester bag-derived degradability estimates}

In the polyester bag procedure, all $\mathbf{N}$ disappearing from the bag is assumed to be degraded to ammonia or directly incorporated into microbial $\mathrm{N}$, although there is no direct evidence in support of this. However, the degradability values obtained using the procedure, together with the measured rumen outflow rates, were similar to those derived from duodenal-flow measurements, being slightly lower for the three plant materials and slightly higher for the FM. Kennedy et al. (1982) also found reasonably good agreement between the two procedures when used to estimate the $\mathrm{N}$ degradability of brome-grass (Bromus inernis) hay and lucerne (Medicago sativa) hay and rolled barley in the sheep rumen.

The polyester bag procedure, when coupled with rumen outflow rate measurements, could not be considered sufficiently rapid for the routine screening of feedstuffs, although its applicability for such a purpose would be greatly improved if an assumed outflow rate or, better still, $\mathrm{N}$ loss at a fixed incubation time, could be taken as representing rumen degradability. These two possibilities have been examined (Table 8) using the results of the present study and those of Kennedy et al. (1982) and Mathers \& Miller (1981). In all three studies, $\mathrm{N}$ degradability in the sheep rumen was determined from abomasal- or duodenal-flow measurements and from polyester bag and rumen-outflow measurements. Only fluid outflow rate was determined in the study of Mathers \& Miller (1981), and they found better agreement between the two procedures by assuming a particulate matter outflow rate of $0 \cdot 046 / \mathrm{h}$. In Table 8 an assumed outflow rate of $0 \cdot 030 / \mathrm{h}$ was used for all feedstuffs as this was the mean of the outflow rates calculated for each feedstuff such that the polyester bag-derived estimate was the same as that derived from duodenal-flow measurement. When the single outflow rate for all feedstuffs was used, the agreement between the two procedures was as good, if not better than when the measured outflow rate was used. Examination of the $\mathrm{N}$ disappearance curves in the three studies showed that for a single incubation time, $\mathrm{N}$ loss at $15 \mathrm{~h}$ provided the best overall agreement with the duodenal-flow-based estimates and, for most feedstuffs, $\mathrm{N}$ loss at $15 \mathrm{~h}$ was as close to the duodenal flow estimates as the estimate derived using rumen outflow rate. However, in a more recent study, Kennedy et al. (1984) found very poor agreement between the duodenal-flow and polyester bag procedures when used to estimate the $\mathrm{N}$ degradability of a diet containing chopped reed canary grass (Phalaris arundinacea) and lucerne hay. They also suggested that the good agreement found for brome-grass hay in their previous study (Kennedy et al. 1982) was due to the use of an unreliable method for estimating the proportion of microbial $\mathrm{N}$ in abomasal digesta.

\section{In vitro measurement of degradability}

A variety of different solvents and procedures have been used for measuring feedstuff N solubility (e.g. Wohlt et al. 1973; Waldo \& Goering, 1979) and have generally shown, 
Table 8. Comparison of nitrogen degradability values derived from duodenal flow measurements and from polyester bag- $N$ disappearance using an assumed outflow rate $(0.03 / h)$ or a fixed incubation time $(15 \mathrm{~h})$

\begin{tabular}{|c|c|c|c|c|c|c|}
\hline & & & \multicolumn{4}{|c|}{$\mathrm{N}$ degradability } \\
\hline & & & \multirow{3}{*}{$\begin{array}{l}\text { Duodenal } \\
\text { flow }\end{array}$} & \multicolumn{3}{|c|}{ Polyester bag } \\
\hline & \multicolumn{2}{|c|}{ Outflow rate $(/ \mathrm{h})$} & & Measured & Assumed & \\
\hline & Measured & Calculated ${ }^{*}$ & & & $(0.03 / \mathrm{h})$ & incubation \\
\hline $\begin{array}{l}\text { Ryegrass hay } \\
\text { (Lolium perenne) } \dagger\end{array}$ & ND & 0.023 & 0.76 & ND & 0.73 & 0.71 \\
\hline Soya-bean meal $\dagger$ & 0.034 & 0.020 & 0.88 & 0.82 & 0.83 & 0.89 \\
\hline Groundnut meal $\dagger$ & 0.038 & 0.023 & 0.76 & 0.67 & 0.71 & 0.67 \\
\hline Fish meal $\dagger$ & 0.030 & 0.036 & 0.57 & 0.60 & 0.59 & 0.53 \\
\hline Rolled barley $\ddagger$ & 0.026 & 0.007 & 0.90 & 0.84 & 0.83 & 0.84 \\
\hline $\begin{array}{l}\text { Lucerne } \\
\text { (Medicago sativa) hay } \ddagger\end{array}$ & 0.054 & 0.007 & 0.80 & $0 \cdot 71$ & 0.75 & $0 \cdot 76$ \\
\hline $\begin{array}{l}\text { Brome-grass } \\
\text { (Bromus inernis) hay } \ddagger\end{array}$ & 0.064 & 0.049 & 0.60 & 0.56 & 0.66 & 0.61 \\
\hline Dried lucerne (DL)\$ & 0.060 & $0 \cdot 053$ & 0.72 & 0.67 & 0.77 & 0.83 \\
\hline Rolled barley (RB) $\S$ & $0.090 \|$ & $0 \cdot 050$ & 0.86 & 0.84 & $0 \cdot 88$ & 0.92 \\
\hline DL:RB $(2: 1) \S$ & $0 \cdot 150 \|$ & 0.034 & 0.76 & 0.52 & 0.77 & 0.78 \\
\hline $\mathrm{RB}: \mathrm{DL}(2: 1) \S$ & 0.090 & 0.023 & 0.86 & 0.72 & $0 \cdot 84$ & 0.87 \\
\hline
\end{tabular}

$\mathrm{ND}$, not determined.

* Calculated such that the polyester bag- and duodenal-flow-derived estimates of degradability were the same.

$\uparrow$ Present study.

$\ddagger$ Kennedy et al. (1982).

$\S$ Mathers \& Miller (1981).

$\|$ Outflow rate of fluid.

as found in the present study, solvent differences between mineral buffers, $\mathrm{NaCl}$ and distilled water to be small. $\mathrm{N}$ solubility in these solvents did not rank the feedstuffs in order of their in vivo degradabilities. Owens (1978) concluded that the correlation between buffer $\mathrm{N}$ solubility and rumen degradability accounted for less than one-third of the total variability. However, since soluble nitrogenous compounds are rapidly degraded in the rumen (Annison, 1956), measurement of buffer-soluble $\mathrm{N}$ may be of value in terms of balancing diets for their rapidly fermentable $\mathrm{N}$ and energy contents, and a more efficient utilization of the $\mathrm{N}$ in diets with a lower soluble $\mathrm{N}$ content has been observed (Aitchison et al. 1976; Wohlt et al. 1976; Wanapat et al. 1982; Baxter et al. 1983).

$\mathrm{NaOH}$ solubilized considerably more of the feedstuff $\mathrm{N}$ than the other solvents and also ranked the supplements, although not the hay, in the same order as their in vivo $\mathrm{N}$ degradabilities. Furthermore, when the solubilization procedure was carried out at room temperature, the proportion of the supplement total $\mathrm{N}$ solubilized was very similar to the value for in vivo $\mathbf{N}$ degradability derived from duodenal-flow measurements. This agreement may have been fortuitous but deserves further examination. If confirmed, $\mathbf{N}$ solubility in mineral buffer and $\mathrm{NaOH}$ would provide a relatively simple procedure for the characterization of the $\mathrm{N}$ in protein supplements into that which is rapidly degradable and that which is more slowly degraded.

Pichard \& Van Soest (1977) proposed a procedure based on digestion by neutral protease for fractionating the nitrogenous constituents of ruminant feeds into four categories: a water-soluble NPN fraction, a rapidly degraded protein fraction, a less rapidly degraded 
protein fraction and an unavailable fraction. In the present study the ranking of the feedstuffs, in terms of the proportion of the total $\mathrm{N}$ digested by proteolytic enzymes, was found to vary, depending on the nature of the proteolytic enzyme used (i.e. protease, pancreatin or pepsin), the enzyme: substrate value and the length of the incubation time. However, it was not possible to identify conditions under which the procedure ranked the feedstuffs or even the supplements in the same order as the in vivo degradability procedures.

Ammonia production during incubation with rumen fluid would appear to rank the supplements, but not the hay, in the same order as the in vivo degradability procedures, provided an incubation time of between 6 and $24 \mathrm{~h}$ was used. Chamberlain \& Thomas (1979) also found that the in vitro ammonia-production procedure ranked casein, SBM, GNM and $\mathrm{FM}$ in order of their expected in vivo $\mathrm{N}$ degradabilities, whereas $\mathrm{N}$ solubility in buffer and digestion with protease did not. However, in both the present study and that of Chamberlain \& Thomas (1979), the ammonia produced expressed as a proportion of the feedstuff total $\mathbf{N}$ was much lower than the estimated in vivo degradability. Soluble total NPN production, i.e. ammonia plus amino acids and peptides, also ranked the supplements in the same order as the in vivo procedures, and gave higher degradability estimates than those derived from ammonia production, but still lower than the in vivo estimates. The concentration of ammonia or soluble total NPN in the incubation mixture is the net result of its rate of production by $\mathrm{N}$ degradation and rate of utilization by the microbes. The latter is energy dependent, and a higher readily fermentable carbohydrate content in the hay than in the supplements would explain why net ammonia production with the hay was lower than with the supplements. Ammonia assimilation by the microbes can be inhibited by the inclusion of hydrazine sulphate in the incubation mixtures (Broderick \& Balthrop, 1979), but it also inhibits amino acid deamination, and therefore feedstuff $\mathrm{N}$ degradability can only be assessed in terms of soluble total NPN production. As expected, soluble total NPN production with the hay was increased by the presence of hydrazine sulphate, whereas with the supplements it was either unaffected or reduced. The reduction was most marked with SBM, such that the procedure did not rank the supplements in the same order as their in vivo degradabilities.

The authors wish to thank Mr M. S. Dhanoa for his help with the statistical analysis of the results.

The Animal and Grassland Research Institute is financed through the Agricultural and Food Research Council, and the work formed part of a commission from the Ministry of Agriculture, Fisheries and Food.

\section{REFERENCES}

Agricultural Research Council (1980). The Nutrient Requirements of Ruminant Livestock. Farnham Royal: Commonwealth Agricultural Bureaux.

Aitchison, T. E., Mertens, D. R. \& Jacobson, N. L. (1976). Journal of Dairy Science 59, 2056-2062.

Annison, E. F. (1956). Biochemical Journal 64, 705-714.

Baxter, H. D., Montgomery, M. J., Waldo, D. R. \& Owens, J. R. (1983). Journal of Dairy Science 66, $2093-2099$.

Broderick, G. A. \& Balthrop, J. E., Jr (1979). Journal of Animal Science 49, 1101-1111.

Chamberlain, D. G. \& Thomas, P. C. (1979). Proceedings of the Nutrition Society 38, 138 A.

Engelhardt, V. W. \& Hauffe, R. (1975). In Digestion and Metabolism in the Ruminant, pp. $216-230$ [I. W. McDonald and A. C. I. Warner, editors]. Armidale, Australia: the University of New England Publishing Unit. Faichney, G. J. (1975). Australian Journal of Agricultural Research 26, 319-327.

Ganev, G., Orskov, E. R. \& Smart, R. (1979). Journal of Agricultural Science, Cambridge 93, $651-656$.

Gehrke, G. W., Kaiser, K. E. \& Ussary, J. P. (1968). Journal of the Association of Official Analytical Chemists 51, $200-211$.

Grovum, W. L. \& Williams, V. J. (1973). British Journal of Nutrition 30, 313-329.

Harrop, C. J. F. (1974). Journal of Agricultural Science, Cambridge 83, 249-257.

Kennedy, P. M., Christopherson, R. J. \& Milligan, L. P. (1982). British Journal of Nutrition 47, 521-535. 
Kennedy, P. M., Hazelwood, G. P. \& Milligan, L. P. (1984). British Journal of Nutrition 52, $403-417$.

McDonald, I. (1981). Journal of Agricultural Science, Cambridge 96, 251-252.

McDougall, E. I. (1948). Biochemical Journal 43, 99-109.

MacRae, J. C. (1975). In Digestion and Metabolism in the Ruminant, pp. 261-276 [I. W. McDonald and A. C. I.

Warner, editors]. Armidale, Australia: University of New England Publishing Unit.

Mathers, J. C., Horton, C. M. \& Miller, E. L. (1977). Proceedings of the Nutrition Society 36, 37 A.

Mathers, J. C. \& Miller, E. L. (1981). British Journal of Nutrition 45, 587-604.

Mehrez, A. Z. \& Ørskov, E. R. (1977). Journal of Agricultural Science, Cambridge 88, 645-650.

Miller, R. G. (1966). Simultaneous Statistical Inference. New York: McGraw-Hill.

Nolan, J. V. \& Leng, R. A. (1974). Proceedings of the Nutrition Society 33, 1-8.

Ørskov, E. R. (1977). Proceedings of the 2nd International Symposium on Protein Metabolism and Nutrition, pp.

110-114. Wageningen: Centre for Agricultural Publishing and Documentation.

Ørskov, E. R. \& McDonald, I. (1979). Journal of Agricultural Science, Cambridge 92, 499-503.

Ørskov, E. R. \& Mehrez, A. Z. (1977). Proceedings of the Nutrition Society 36, 78 A.

Osbourn, D. F. \& Siddons, R. C. (1980). Annales Zootechnie 29, 325-336.

Owens, F. N. (1978). Feedstuffs 50, 23-24, 39.

Pichard, G. \& Van Soest, P. J. (1977). Proceedings of the Cornell Nutrition Conference, pp. 91-98.

Siddons, R. C., Beever, D. E. \& Nolan, J. V. (1982). British Journal of Nutrition 48, 377-389.

Siddons, R. C. \& Paradine, J. (1981). Journal of the Science of Food and Agriculture 32, 973-981.

Siddons, R. C. \& Paradine, J. (1983). Journal of the Science of Food and Agriculture 34, 701-708.

Uden, P., Colucci, P. E. \& Van Soest, P. J. (1980). Journal of the Science of Food and Agriculture 31, 625-632.

Van Soest, P. J. \& Wine, R. H. (1967). Journal of the Association of Official Analytical Chemists 50, 50-55.

Waldo, D. R. (1978). Proceedings of the Georgia Nutrition Conference for the Feed Industry, pp. 13-20.

Waldo, D. R. \& Goering, H. K. (1979). Journal of Animal Science 49, 1560-1568.

Wanapat, M., Erickson, D. O. \& Slanger, W. D. (1982). Journal of Animal Science 54, 625-631.

Wohlt, J. E., Sniffen, C. J. \& Hoover, W. H. (1973). Journal of Dairy Science 56, 1052-1057.

Wohlt, J. E., Sniffen, C. J., Hoover, W. H., Johnson, L. L. \& Walker, C. K. (1976). Journal of Animal Science 42, $1280-1289$. 